\title{
Cultural Diplomacy 2.0: Challenges and Opportunities in Museum International Practices
}

\author{
Natalia Grincheva*
}

\begin{abstract}
This study discusses several issues that museums face when utilizing social media in their international communication. This discussion is framed within the discourse of the new cultural diplomacy and this paper proposes a specific role for museums in cross-cultural diplomatic relations. This new model for contemporary museums as vehicles for a 'trans-cultural encounter', or a 'forum' is based on the shift within museum institutional structures across communication, educational and political dimensions.

Drawing on empirical materials, this study identifies three specific ways in which museums can use social media in their international diplomatic endeavours. The first section discusses how social technology can aid museums in responding to issues and concerns originating from foreign communities. This is followed by a discussion of how social media can connect foreign audiences to the cultural content of museums through direct participation activities. Finally, social media can enhance cultural exchange among people from different cultural communities by bringing them together online for collaborative activities.
\end{abstract}

Key words: cultural diplomacy, museums, social media, cultural exchange, online communication, cultural participation

\section{Introduction}

As McLuhan imagined, the rapid development of information technologies and new media communication have transformed the fundamental principles of contemporary society, operating in a world that is increasingly global and virtual (McLuhan 1962). Despite the escalating interconnectedness of various cultural communities on a global scale through social media in the shared communication space of the Internet, issues of cross-cultural understanding, tolerance, and respect still remain imperative. Manuel Castells stresses: 'Rather than the rise of a homogeneous global culture, what we observe as the main common trend is historical cultural diversity: fragmentation rather than convergence' (Castells 2004: 38). Within global contexts, communication issues have become even more sensitive and it has become necessary to find effective means that can decrease 'systematic misunderstanding, at the roots of destructive violence against the other' (Castells 2004: 39).

Cultural diplomacy has traditionally been 'an instrument ... and a way of interacting with the outside world' (Gienow-Hecht and Donfried 2010: 11). Cultural diplomacy implies the use of the art of diplomacy in promoting culture resulting in a potential greater awareness of each other's cultural backgrounds. Such awareness can lead to interaction among various players, states, and individuals. These interactions are usually achieved through the organization of events or a series of cultural activities among countries and employing the instrumentality of 'culture' in promoting a country's interests in economic, political, and strategic fields. Defined as 'the exchange of ideas, information, art and other aspects of culture among nations and their peoples to foster mutual understanding' (Cummings 2003), cultural diplomacy aims to bring people from different countries together so they can learn about each other's cultures and traditions. 
However, the old principles of cultural diplomacy based on a 'top-down branding approach, which treats people as targets rather than participants in an exchange of views' (Leadbeater 2010) is no longer relevant. With significant changes in the global culture of communication, the traditional principles of cultural diplomacy such as image cultivation, propaganda, and marketing-oriented activities (Melissen 2006: 3) have proved to be outdated diplomatic strategies. American culture climatologist and persuasion/propaganda expert Nancy Snow points out that "global publics will not allow themselves just to be talked to, but are demanding fuller participation in dialogue and feedback through the help of Web 2.0 communication technologies and new media' (Snow 2009: 8). The change in the cultural diplomacy paradigm can be described 'as the shift from few-to-few communication (traditional diplomacy) to ... the growth of many-to-many interactions' (Bound et al, 2007: 75).

New media offers an accessible and affordable platform for interactive engagement among people from different countries to enable collaboration and discourse. The potential of social media to reach wider, more diverse audiences and to establish communication through a faster and easier mode with a variety of different actors has been recognized by many countries. Wealthy countries with leading economies in Europe and North America enthusiastically advocate adding social media to the toolbox of public and cultural diplomacy. ${ }^{1}$

Historically, national cultural institutions, such as museums, have traditionally been important cultural policy actors in nation states with the goal of building cultural bridges across borders whether by developing cultural tourism or by facilitating diplomatic dialogue with foreign nations. For example, the British Museum in London has served as an important diplomatic actor since its foundation following its fundamental principles established by Parliament in 1753: 'To allow visitors to address through objects, both ancient and more recent, questions of contemporary politics and international relations' (MacGregor 2004).

Museums are serving as central nodes in social cultural networks formed by states, governments, and communities to cultivate national character based on the premise that 'culture is an incubator of character' (Luke 2002: 230). By playing a strong educational role (Hooper-Greenhill 2010), museums are powerful forces that shape and define collective values and social perceptions in national contexts. Museums might not be powerful enough to instantly change public policies in the country. However, museums are able to influence larger cultural values of people that will consequently alter policies (Luke 2002: 230).

Bennett emphasizes that museums have always exercised the power to reinterpret the meaning of their collections and objects through a variety of different conceptions employed to reorganize exhibition displays and spaces (Bennett 1995: 97). This political power of cultural representation is crucial, especially when it concerns representing the 'others' in a museum setting. Misinterpretation of cultural content can distort meanings and alter facts, encouraging dangerous and destructive attitudes in the national community toward the other cultures (Anderson 2004: 67). Deployed propagandistically, such misrepresentation can manipulate cultural views, assert nationalism, evoke cultural phobias, and cause cultural separatism (Cameron 1991; Karp 1991; Luke 2002; Wallis 2004).

As Bennett suggests, cultural separatism can be treated best by facilitating interactions among cultures and involving all cultural groups equally in collaborative activities (Bennett 2001: 22). Within the institutional structure of museums, this can be implemented only if the museum is understood as a social venue, or a 'forum'. According to Duncan Cameron, transforming a museum into a 'forum' from a 'temple' is crucial to providing a comfortable meditative space, where cultures can meet and debate to create a polyphonic narration accounting for 'the most radical innovations in art forms, the most controversial interpretations of history, of our own society, of the nature of man, or, for that matter, of the nature of our world' (Cameron 1971: 12).

The 'forum' and the 'temple' models of the museum recall the analogy of the 'cathedral' and the 'bazaar' paradigms introduced by Raymond in his famous book about open source software communities where he coined the term 'open source'. The open source approach first applied solely to the open code software available online for free access, re-coding, and sharing (Raymond 2001). Later, the term was borrowed by many scholars from various disciplines to describe a new type of social organization emerging on the Internet that has become a philosophical conception. In this paradigm, the 'cathedral' refers to traditional top-down 
organizations defining the power hierarchy of authority in organizations, similar to the 'temple' museum model. The 'bazaar' is an open-structured decentralized network built on the principles of social inclusion, free production, consumption, and sharing, which resembles the museum 'forum' structure (Raymond 2001). In increasingly globalized organizations, a 'forum' museum model suggests a new understanding of the diplomatic and mediating role of museums as leaders of online cultural exchanges (Sayers 2010).

The rapid advance of social media increased the demands of the networked society and reposed sharply the questions for museums that have been critical for them since the emergence of the new museology movement in 1970s. Over the past decades, the museum communication system has been transforming from the modernist information transmission model to a social constructivist model focusing on the experiences of the audiences who are treated as active meaning-makers (Vergo 1997; Hein 1998; Hooper-Greenhill 2000). The issues that social media has accentuated include sharing authority with audiences and allowing them to become active meaning-making creators in the exhibition narrations; providing participatory opportunities for visitors that enhance learning in the museum and connect visitors to the collections, and the creation of interactive community around museum content that brings together people from disperse cultural groups for collaborative activities.

This study suggests three specific ways of how museums can use social media in their international diplomatic endeavours. The structure of this paper consists of three major parts. The first section discusses how social technology can aid museums to respond to issues and concerns originating from foreign communities in regard to their national representation in the museums' exhibitions. The following part describes how social media can connect foreign audiences to museum cultural content through direct participation activities. Finally, the last section discusses how social media can enhance cultural exchange among ordinary people from different cultural communities by bringing them together for collaborative activities. By providing illustrative examples from museum online activities, the study attempts to articulate and start a discussion on opportunities and challenges, brought by the web 2.0 communication technologies for cross-cultural interactions in a museum context.

\section{Cultural Voices through Social Media}

Misrepresentation of cultural values and beliefs in expositions can result in the evocation of dangerous nationalistic attitudes in a society and can create cross-cultural misunderstandings that break trust and raise conflicts. As a main goal of cultural diplomacy is to 'help create a better climate of international trust and understanding...' (US Department of State 1969: iv), social media can be very instrumental for museums by providing a meditative space where cultural concerns expressed by representatives from other communities can be heard in real time and also by providing an opportunity for responses to these issues to be both immediate and constructive.

As Karp points out, 'No genre of museum is able to escape the problems of representation inherent in exhibiting other cultures' (Karp 1991: 378). That makes museum exhibitions a controversial display that can decrease cross-cultural understanding if such exhibition spaces are not turned into an open space for debate, or 'forum', where a polyphony of cultural voices can contribute to collaborative narration creation. Within the physical venue of a museum, providing a place which is open for discussion can be problematic and, in fact, even impossible. However, a social media environment can potentially serve as a robust platform that enables various culture representatives to sound their concerns about misrepresentation or misinterpretation of cultural content displayed in the museum context.

Projects developed within the framework of the US Museums \& Community Collaborations Abroad (MCCA) programme can illustrate how people from indigenous communities can contribute to the creation of museum narrations around cultural artefacts. One such project, commissioned recently by the State Department's Bureau of Educational and Cultural Affairs, aims to develop an online platform to connect the University of Colorado Museum of Natural History (USA) and the National Taiwan Museum located in Taipei City.

Through this platform, indigenous peoples from local communities in Taiwan and the USA can gain remote access to the two museums' collections. This will enable the museums 
to document authentically the intangible aspects of the cultures that they present and disseminate information further to broader audiences. As a result, this collaborative online platform will accumulate 'stories, oral histories, material culture, and audiovisual materials that illustrate indigeneity as it is experienced and practiced in the East and in the West by the Navajo Nation in the United States and the Paiwan people of Taiwan.' ${ }^{2}$ Furthermore, the programme empowers the connection among distant indigenous peoples to expand further opportunities for collaboration between native communities from different countries.

In recent years, museums have been attempting to address cross-cultural representation issues in their exhibition programming through community consultations (Fouseki 2010: 180). However, as research reveals, in many cases such attempts were not successful due to the fact that consultations are designed simply to ask opinions about authoritative decisions rather than to engage with communities on making the decisions. Fouseki argues that active negotiation and engagement aimed at shared power and ownership can solve this problem (Fouseki 2010: 180).

The issue of sharing authority has been a long standing debate among museums since the advance of new museology. With the emergence of web 2.0, this problem has moved to the heart of discourse about social media threats to museums' public images. Because museums have traditionally served as the most credible sources of information, inviting audiences to contribute to museums' narration is quite uncomfortable from museums' point of view. According to the American Association of Museums' survey on public trust of various sources of information, 'museums are the most trusted source of information, ahead of books and television news' (MacArthur 2010). Considering this fact, the risk of the erosion of authority hierarchies and the allowance of low barriers of entry in online communication processes can significantly decrease the overall quality of museum content.

However, web 2.0 provides multiple tools for online visitors to sound their opinions without associating their voice with the institution. For example, an open dialogue social network like Facebook allows online visitors to converse around various issues on museum profile pages simultaneously making it possible, at the user's request, to display only institutional information.

Additionally, there are many strategies that can be employed, first, to ensure the quality of audience contributions and, second, to frame visitors' responses to particular issues. The act of making communication clear and transparent by identification of who is talking to whom and about what, as well as framing audience comments as an engaging democratic dispute, will not harm the institutional 'brand'. On the contrary, it can even aid in attracting more audiences and enhance the museum's image as a democratic forum for open debate.

When structuring the multitude of visitors' contributions to the online discussion, the differentiation of access can also be helpful in ensuring quality. As Trant of Archives and Museum Informatics indicates, trusting the audiences is based first of all on knowing the audiences and assigning proper levels of access. 'Trust is built on identity; identity requires identification... Assessments of trust require a history of an individual's actions - linking their traces with a distinct identity. Individuals build trust by behaving appropriately, over time' (Trant 2006).

Furthermore, because even among the same communities there exists a great diversity of voices and attitudes, there is no universal way to represent properly various cultures by addressing all concerns and respecting a multitude of opinions. That is why a personalized approach can make the cultural experiences of online visitors more satisfactory and enriching.

Personalization could be a great way for ... museums to build connections between collections and individuals and between people and collecting institutions... we need to realize that we're creating an on-line space that doesn't share all the characteristics of our past space, on-line or on-site (Trant 2006).

Also, web 2.0 capacities can provide visitors with opportunities to become powerful co-curators that are restricted in the physical museum spaces. The ability to curate can significantly enhance distinct international audience perceptions of how their cultures are presented online in their own individual contexts by enabling them to collect, manipulate, share and interact in 
other forms with cultural artefacts from museum collections. 'Creating a personal museum may provide online participants "with a sense of mastery", in this way digitized collections promote the public ownership of the museum making it a more democratic and inclusive institution' (McTavish 2006). Such an interaction with cultural content not only can help to personalize an individual experience but can also enable active engagement with the museum's content based on participatory experiences.

\section{Cultural Exchange through Participatory Learning}

As Snow emphasizes, new cultural diplomacy is build on the genuine appreciation of the public and sharing culture with other countries cannot be exercised any longer through a one-way direction (Snow 2009: 8). By empowering international audiences to participate actively in educational museum activities, museums can better facilitate the cross-cultural exchanges of ideas and attract more audiences to the cultural content that they promote. Effective management of the relationship between cultural heritage owned by museums and new digital cultural content creation can improve the understanding of cultures through active participatory learning.

Taking into account that understanding and appreciating other cultures is better facilitated through learning experiences, the educational function of museums is becoming imperative for effective cultural diplomacy. Though as Hooper-Greenhill emphasizes, museums traditionally have served as educational institutions that provided a knowledge resource for their communities, in recent decades there has been a shift of the museum's educational role from being a repository of authoritative knowledge to a dynamic storage of information available to visitors for learning in their own ways (Dierking 2006; Hooper-Greenhill 2006).

One such project that provides both learning and participatory opportunities was developed and implemented by the British Museum in cooperation with the BBC in 2010. The educational series on BBC Radio 4, A History of the World in 100 Objects utilized the storytelling powers of objects to connect histories across the globe by presenting a narrative world history told by different museums and people from various countries. The partnership of the British Museum with the BBC ensured the widest possible access to the project and engagement across radio, television and online media platforms.

'A History of the World' web site was developed to provide a main interactive communication platform for the project. It offers opportunities not only to listen to a radio series featuring stories about the objects, but also to explore the bank of the artefacts created through collaborative efforts where contributors can take an active part in the project and submit their own objects and stories. This exciting initiative aims to encourage people from various cultural communities 'to offer pictures of objects they own and explain how these objects can help tell a history of the world.'3 The major ambition of the project was to create an exclusive digital museum online, a database of visual, textual and audio information, which can 'tell history through the eyes of museums and audiences'.

A cross-media presence, through radio and online mediums sustained a high level of public interest in the project which can be evidenced in 18 million podcast downloads (worldwide) of the radio broadcasts in 2010 from the project site (Cock 2011). From the launch of the website, the audience was invited 'to upload details of an object in their possession, something that they believed told a global story analogous to the Museum objects' (Cock 2011). However, to ensure the high quality of public contributions, clear instructions for the call to action were provided on the main information pages. Overall, 4,000 objects throughout the year were uploaded to the website by the public. Though this is only 0.1 per cent of visits to the site, the project managers believe that it still a very good result due to 'the complex nature of the call to action' (Cock 2011).

Apart from the ability to submit objects and stories, the web site also provided some other ways to participate in the project. Each object page has a comments thread where museum partners and online visitors were invited to leave their opinions, ideas and questions or to add more information to the project description. Also, the museum curators host a blog to encourage visitors to engage in discussions related to featured objects.

Though this project clearly demonstrates the potential of social media to involve people from all over the world in a direct interaction with cultural content, many problems evolve when 
participation is incorporated into the educational programs of museums. The use of social media by museums creates an 'open-ended cultural information space' which can be ambiguous from the point of view of structure, content and objectives. As a result, Russo distinguishes the following issues that arise when participatory activities are incorporated into museum programmes online. To start with, museums lose their powers to control the result of such participation and cannot predict exactly how social media will be used by visitors. Also, it is not possible to predict the total number of participants, which can cause technical problems including download speed. Additionally, the duration of such participatory programmes is always questionable as it is not clear for how long the level of audience interest and active participation will sustain the project online (Russo 2007: 25). For many museums this ambiguous situation might seem very uncomfortable and can keep them away from engaging in web 2.0 activities with their audiences.

Nevertheless, as Castells advocated, the participatory opportunities provided for museum online visitors from dispersed cultural communities can be a good way to enable communication between different cultures on the basis of sharing the value of communication as a process. This process-oriented type of communication ('participation for the sake of participation', 'creativity for the sake of creativity') (Castells 2004: 40) does not focus on the end results. Consequently, it can provide a means for participants from diverse cultural backgrounds to enjoy the contemporary pleasures of networked society, simultaneously creating deeper connections to the cultural content while learning from museum recourses.

However, as Witcomb points out, interactive programmes in museum contexts designed for individual participation can alienate visitors from their social context while engaging in learning processes through museums. The author emphasizes the importance of the interaction with other visitors as a meaningful part of the museum experience (Witcomb 2006). Thus, museum learning theories in recent years have been increasingly related to the notion of 'communities of practice' or social-cultural theories that emphasize direct interaction among museum visitors.

\section{Direct People-to-People Cultural Exchange}

Co-participation within the social context of museum communities strengthens the ties between participants and can be an instrumental means of cultural diplomatic initiatives in museums. As discussed earlier, cultural diplomacy can be defined as 'the exchange of ideas, information, art and other aspects of culture...' (Cummings 2003) through 'the direct and enduring contact between people of different nations...' (US Department of State 1969: iv). In this regard, social media provides opportunities for people from different countries (with Internet access) to engage in various ongoing collaborative activities by establishing a stable, reliable and affordable platform that facilitates conversations and makes it easy to exchange digital information including text, video, audio, and multimedia applications. Implementing such crosscultural exchange activities can significantly enhance the social capacity of online museums communities and not only increase audiences but also make cultural contact among online museums visitors from foreign countries more meaningful, educative and engaging.

One of the most recent online participatory projects of the Tate Modern Gallery is the Turbinegeneration project. UNESCO granted its patronage to the project as it clearly supports the major objectives of the international cultural organization in fostering cultural diversity and facilitating intercultural dialogue. ${ }^{4}$ Turbinegeneration is a unique programme that connects schools, galleries and artists from different countries to explore international cultures and exchange artworks online. This collaboration and exchange is facilitated in the online social network created specifically for the project. The network provides an opportunity for members to create a partnership blog where they can share and develop artwork together. The site also makes it easy to upload photographs, video, audio and text. To insure better collaboration among partners, the Tate has developed a free downloadable project pack suggesting a range of activities to initiate and maintain dialogue between schools and artists.

Each year, the Turbinegeneration project is based on the ideas and current topic of The Unilever Series installation. The end goal of the collaboration between participants is a creation and submission of their work to be considered for the online gallery. There are four online shows 
a year, each curated on a specific theme. The final submissions to the shows are moderated by the community manager of the site in consultation with the curator. Every year the number of participating countries increases. From 2009-2010, 16 countries were involved. By 2012, Tate planned to bring to the network schools and galleries from over 30 countries.

Interaction among the museum visitors online is an important aspect of their engagement in the process of learning. Interaction stresses the social nature of museums that "promotes respect among users, encourages community development, and supports interaction beyond the scope of the content' (Simon 2007). Hooper-Greenhill, in referring to new interpretive methodologies that are required to assess visitors' experiences, points to the new education systems emerging in museums introduced by Gaea Leinhardt in her book Learning Conversations in Museums (Hooper-Greenhill 2006). Leinhardt stresses the social act of learning in museums and indicates that a successful museum experience results in a successful collaborative and engaging communication with peers, friends, curators and other groups (Leinhardt 2002: ix).

However, it is important to note that social media bring changes to human communications because they add a layer of technology between communicating partners. All communication in online communities or online social networking is computer-mediated. While some researchers optimistically declare the Internet as a universal means to connect people from different parts of the world, others point out that when culturally diverse individuals interact online, there is a great possibility for misunderstanding, miscommunication and mismatch of values and expectations (Hart 1998).

Intercultural communication has long been recognized by many scholars as a challenge. With the appearance of online communication, it has become even more complicated as it is based on an absence of visual and oral cues. Online community participants, assumed to be culturally diverse, may have different expectations of how to establish trust, support and credibility; exchange information, give and receive feedback, or critique; and/or evaluate different types of information. When designing interactive programmes for online visitors in the museum context, it is indeed crucial to acknowledge all the issues that might arise among participants from different cultural backgrounds online (Barnes 2003; Amant 2007).

However, drawing on Castells' networked society framework, it is possible to suggest that the shared genuine interest in museum content and a desire to collaborate with individuals who share similar interests and passions can potentially make the communication of participants from different countries productive and successful. Because the culture of online communities made up of geographically dispersed individuals is shaped by the "power of networking for the sake of networking' (Castells 2004: 41), it can foster cross-cultural learning and meaningful exchange, if properly mediated by online museums. The social power of an online community brings a lot of hope to the new cultural diplomacy that now can target larger populations and facilitate a wider scope of direct contact between ordinary people from various countries.

\section{Conclusion}

The field of new cultural diplomacy based on web 2.0 standards, as well as the research on the use of social media in museums are still new. Few academic papers have been written on either subject; furthermore, there is no research so far that aims to measure the major cultural impacts of cultural diplomacy initiatives implemented through social media. This paper attempts to introduce a theoretical framework that can give a start for more productive and more focused studies of museums as active actors of the new cultural diplomacy, based on the open source approach.

The present study discusses several issues that museums face when utilizing social media in their activities designed for audience outreach and involvement. The study suggests a specific role for museums to take in cross-cultural diplomatic relations. This new model for a contemporary museum as a 'trans-cultural encounter', or a 'forum' is based on the shift in museum institutional structures across communication, educational and political dimensions. This shift transforms a museum from an authoritative cultural content supplier to a facilitator of cross-cultural experiences that brings different nations together in an engaging international community, where visitors can explore their own ideas and reach their own understanding.

The diplomatic mediating role of contemporary museums can be significantly enhanced 
by social media. A social web creates a global platform that enables museums to 'provide information and knowledge for a range of visitors to access on their terms, through their own choices, and within their own place and time' (Russo 2007). Furthermore, as social media encourages knowledge, information, and cultural exchange through networking, museums as diplomatic actors can use these powers not only to educate international audiences about the cultures they represent, but also to encourage foreign visitors to share their museum experiences and relate them to their own cultures and contexts.

The present study only initiates a conversation on the museum diplomatic role in the realm of digital communication. Further research, both theoretical and empirical, is required to test the claims being made in the present discussion. Therefore, it is imperative to explore how effective online museum diplomacy can actually be by identifying and analysing evidences witnessing a shift of audience attitudes and behaviours towards the other cultures. Furthermore, the study of digital diplomacy could benefit from further in-depth research on the museum online international activities in the context of specific diplomatic challenges across particular countries. Because cultural diplomacy leads to concrete political actions or a change of policies, further more thorough empirical investigation should help to understand if an online museum could really play a vital role in facilitating cross-cultural understanding and changing foreign public's opinions, especially in a time of political crisis or conflict.

Received: 21 August 2011

Finally Accepted: 12 February 2013

\section{Notes}

1 U.S. Department of State (2011) 'Office of e-Diplomacy', http://www.state.gov/m/irm/ ediplomacy/, accessed 02/06/2011

WSIS: World Summit on the Information Society (2011) 'C8. Cultural Diversity and Identity, Linguistic Diversity and Local Content', http://groups.itu.int/Default.aspx?tabid=766, accessed 01/06/2011

Foreign Commonwealth Office UK (2011) 'Digital Diplomacy', http:// digitaldiplomacy.fco.gov.uk/en/, accessed 02/05/2011

Government of Canada (2011) 'Connect 2 Canada', http://www.connect2canada.com, accessed 09/05/2011

2 American Association of Museums (2010) 'i-Share: Connecting Museums and Communities East and West', http://www.aam-us.org/mcca/taiwan09-11.cfm, accessed 09/05/2011

3 The British Museum (2010) 'A History of the World Project' http://www.bbc.co.uk/ ahistoryoftheworld/, accessed 09/05/2011

4 Tate (2010) 'Turbine Generation Project ' http://turbinegeneration.tate.org.uk/, accessed $09 / 05 / 2011$

\section{Bibliography}

Amant, K. (2007) Linguistic and Cultural Online Communication Issues in the Global Age, Hershey, Pa: Information Science Reference

Amant, K. (2007) Linguistic and Cultural Online Communication Issues in the Global Age, Hershey, Pa: Information Science Reference

Anderson, G. (2004) Reinventing the Museum: Historical and Contemporary Perspectives on the Paradigm Shift, Rowman: Altamira 
Barnes, S. (2003) Computer-Mediated Communication: Human-to-Human Communication Across the Internet, Boston: Allyn and Bacon

Bennett,T. (1995) the Birth of the Museum: History, Theory, Politics, London: Routledge

Bennett, T. (2001) Differing Diversities: Cultural Policy and Cultural Diversity, Strasbourg: Council of Europe

Bound, K., Briggs, R., Holden, J. and Jones, S. (2007) Cultural Diplomacy, London: Demos

Cameron, D. (1991). 'Art Museums and the Ritual of Citizenship', in Ivan Karp and Steven D. Lavine (eds), Exhibiting Cultures: the Poetics and Politics of Museum Display, 88103, Washington, D.C.: Smithsonian Institution Press

Cameron, D. (1971) 'The Museum, a Temple or the Forum', Curator: The Museum Journal, 14 (1) $11-24$

Castells, M. (2004) The Network Society a Cross Cultural Perspective, Cheltenham: Edward Elgar Publishers

Cock, M. et al. (2011) 'On Air, Online and Onsite: The British Museum and BBC's A History of the World in J. Trant, Jr. and D. Bearman (eds), Museums and the Web 2011: Proceedings. Toronto: Archives \& Museum Informatics

Cummings, M. (2003) 'Cultural Diplomacy and the United States Government: A Survey', Cultural Diplomacy Research Series, Vol. 1, Center for Arts and Culture

Dierking, J. (2006) 'Museums and Free Choice Learning' in Sharon Macdonald, $A$ Companion to Museum Studies, 325-339, Oxford: John Wiley and Sons

Fouseki, K. (2010) 'Community Voices, Curatorial Choices': Community Consultation for the 1807 Exhibitions', Museum and Society, 8 (3) 180-192

Gienow-Hecht, J. and Donfried, M. (2010) Searching for a Cultural Diplomacy, Oxford: Berghahn Books

Hart, William. (1998) 'Intercultural Computer-Mediated Communication', The Edge: The EJournal of Intercultural Relations, 1 (4) 12-23

Hein, G. (1998) Learning in the Museum, London: Routledge

Hooper-Greenhill, E. (2000) 'Culture and Meaning in the Museum' in Museums and the Interpretation of Visual Culture, 1-22, London: Routledge

Hooper-Greenhill, E. (2006) 'Studying Visitors' in Sharon Macdonald (ed) A Companion to Museum Studies, 362-376, Oxford: John Wiley and Sons

Hooper-Greenhill, E. (2010) 'Changing Values in the Art Museum, Rethinking Communication and Learning', International Journal of Heritage Studies, 6 (1) 9-31

Karp, I. (1991) 'Cultures in Museums Perspectives' in Ivan Karp and Steven D. Lavine (eds) Exhibiting Cultures: the Poetics and Politics of Museum Display, 373- 392, Washington, D.C.: Smithsonian Institution Press

Leadbeater, C. (2010) Cloud Culture: the Future of Global Cultural Relation, London: British Council

Leinhardt, G. (2002) Learning Conversations in Museums, London: Routledge 
Luke, T. (2002) Museum Politics: Power Plays At the Exhibition, Minneapolis, MN: Minnesota Press

MacArthur, M. (2010) 'Can Museums Allow Online Users to Become Participants?', American Association of Museums, Http://Www.Aam-Us.Org/Pubs/Webexclusive/ Digitalmuseum2.Cfm, Accessed 11/4/2011

MacGregor, N. (2004) 'The British Museum', Museums of the World, ICOM, http:// icom.museum/fileadmin/user_upload/pdf/ICOM_News/2004-1/ENG/p7_2004-1.pdf, Accessed 12/4/2011

McLuhan, M. (1962) The Gutenberg Galaxy: The Making of Typographic Man, Toronto: University of Toronto Press

McTavish, L. (2006) 'Visiting the Virtual Museum: Art and Experience Online' in Janet Marstine (ed) New Museum Theory and Practice: An Introduction, 226-245, Oxford: Wiley-Blackwell

Melissen, J. (2006) New Public Diplomacy: Between Theory and Practice, Basingstoke: Palgrave

Raymond, E. (2001) The Cathedral and the Bazaar: Musings on Linux and Open Source by an Accidental Revolutionary, O’Reilly Media, Inc.

Russo, A., Watkings, J., Kelly, L. and Chan, S. (2007) 'Social Media and Cultural Interactive Experiences in Museums', Nordisk Museology, 1, 19-29

Sayers, A. (2010) 'Museums and Their Place in the World', National Museums of Australia' http://Nma.Gov.Au/Research/Staff_Presentations_and_Papers/Lowy/Index.html, Accessed 12/4/2011

Simon, N. (2007) 'Hierarchy of Social Participation', Museum 2.0, Http:// Museumtwo.Blogspot.Com/2007/03/Hierarchy-of-Social-Participation.Html, Accessed 10/4/2011

Snow, N. (2009) 'Rethinking Public Diplomacy', in Routledge Handbook of Public Diplomacy, Annenberg School of Communications (University of Southern California), Center on Public Diplomacy: Taylor \& Francis

Trant, J. (2006) 'Trust, Audience and Community: Museums, Libraries and Identity', Museums and the Web, Http://Conference.Archimuse.Com/Node/106, Accessed 13/ $4 / 2011$

U.S. Department of State (1969) Cultural Diplomacy, International Education Exchange Service, Bureau of International Cultural Relations

Vergo, P. (1997) The New Museology, London: Reaction Books

Wallis, B. (2004) 'Selling Nations: International Exhibitions and Cultural Diplomacy in Museum Culture', in D. Sherman and J. Rogoff (eds) Museum Culture: Histories, Discourses, Spectacles, 265-283, London: Routledge

Witcomb. A (2006) 'Interactivity: Thinking Beyond' in Sharon Macdonald (ed) A Companion to Museum Studies, 353- 361, Oxford: John Wiley and Sons 
${ }^{*}$ Natalia Grincheva is an enthusiastic and energetic international arts project coordinator from Russia, experienced in completing numerous cross-cultural programmes. Currently, she is working on the doctoral project at City University London in the Cultural Policy and Management Programme. Her research is across such disciplines as cultural diplomacy, social media, and new museology. It focuses on the use of social media in museums' international outreach and diplomatic activities. The main objective of the project is to evaluate the impact of cultural diplomacy programmes developed in different countries and implemented online within a museum context

\section{Address:}

131A Shardeloes Road

London

\section{SE14 6RT}

UK

Tel: +447869687033

E-mail: grincheva@gmail.com 